\title{
Microenvironment identification and the feed availability for dairy cows during dry and wet seasons in the main dairy areas of Yogyakarta - Indonesia
}

\author{
Budi Prasetyo Widyobroto - Rochijan - \\ Cuk Tri Noviandi - Andriyani Astuti
}

\section{BP Widyobroto - Rochijan}

Department of Animal Production, Faculty of Animal Science, Universitas Gadjah Mada, Jl. Fauna No. 3, Bulaksumur, Yogyakarta 55281, Indonesia.
CT Noviandi - A Astuti (Corresponding author)

Department of Animal Nutrition and Feed Science, Faculty of Animal Science, Universitas Gadjah Mada, Jl. Fauna No. 3, Bulaksumur, Yogyakarta 55281, Indonesia. email: andriyaniastuti@ugm.ac.id

Received: September 27, 2018 • Revised: December 07, 2018 • Accepted: December 19, 2018

\begin{abstract}
In tropical Indonesia, which has specific dry and wet seasons, it is difficult to provide high-quality forage in sufficient quantities throughout the year. Therefore, it is necessary to establish the availability and nutrient contents of forages and other natural feed resources during the dry and wet seasons in order to provide sufficient nutrients throughout the year, as an improvement effort the productivity of dairy cows. The method used was surveys conducted at dairy smallholder and groups selected in one of the areas of dairy cooperative in Yogyakarta; and observed environment condition (temperature and humidity). Feed samples were taken and analyzed in the Laboratory of Dairy Science and Milk Industry, Faculty of Animal Science UGM. Supplies of forages, agricultural by-products, feedstuffs, and commercial concentrates were available throughout the year, although the amounts were limited. Most of dairy smallholders had greater access to forages and agricultural by-products during wet season than during the dry season; this resulted directly in a better productivity of dairy cows during the wet season. In both seasons, farmers purchased commercial concentrates from other areas to support the cows feed requirements. Smallholder dairy farmers in the dairy areas of Yogyakarta had better access to forages and agricultural by-products during the wet season than during the dry season, but need to supplement their animals with commercial concentrates obtained from outside areas during both seasons. Assuring the continuity and availability of forages and concentrate in this area is of dire importance to reduce the dependency of feed from outside of the region.
\end{abstract}

Keywords: dairy cows, feed, season, tropical environment, temperature humidity index

\section{Introduction}

Indonesia is known as a tropical country and the climate is fairly hot and humid all year rounds. The climate and weather of Indonesia are characterized by two tropical seasons, which vary with the equatorial air circulation (the Walker circulation) and the meridian air circulation (the Hardley circulation), so that weather usually has high temperatures and humidity (Thayeb 2015; Rochijan et al 2016). The weather in Indonesia is characterized by high temperature and humidity, ranging between 27.7 - 34.6oC and, 55.8 and $86.8 \%$, respectively (BPS 2010; Hernawan 2014; Rochijan et al 2016) and temperature humanity index value in Indonesia is $78-80$. Yogyakarta is one of the provinces in Indonesia that is focussed by the government for the development of dairy cow industry. The population of dairy cattle in Yogyakarta is the fourth largest after the provinces of West Java (122,811 head), Central Java (135,069 head) and East Java (274,277 head) with Yogyakarta population in 2016 is 4,181 head (Dirjen PKH 2017). Dairy farmers in Yogyakarta are mostly categorized as smallholder dairy farmer groups, which are independent. The farm is either in the highlands and or the lowlands, and most of which are incorporated in the dairy cooperative. The government of Indonesia is committed to assisting the farmers in managing their dairy cattle, under unfavorable environmental conditions, and unstable dairy cattle productivity and socioeconomic status of dairy farmers (Widyobroto et al 2018). Therefore, it is necessary to establish the feed availability and natural feed resources both in the dry and wet seasons so as to increase the productivity of dairy cattle in the dairy smallholder's in Yogyakarta, particularly in relation to the nutrient content.

Feed is a very important factor in determining the productivity of dairy cattle. The main source of feed for ruminants is forage. Both the quality and quantity of forage need to be adequately sufficient to meet the animal nutrient requirements to ensure their productivity. However, in Indonesia, it seems difficult to provide high-quality forage in 
sufficient quantities throughout the year. This is due to the definite dry season and wet seasons, which determine the growth of forages. In the wet season, the forage grows fast and produce abundant dry matter, while in the dry season, forage does not grow and dry matter production plummeted (Handayanta et al 2014).

In Yogyakarta, most of the dairy farms are situated on the slopes of Mount Merapi. The dairy cattle are mainly fed forages so that the sustainability of a dairy farm depends heavily upon farmers' ability in collecting the forages and the availability of native forages. The highlands has relatively high rainfall and lower temperature compared to the lowlands, which makes the area an ideal place for Friesian Holstein (FH) and Friesian Holstein Crossbreds (PFH) dairy cattle. Forages (grass and forbs) as feed sources for cattle are abundant and grow well. However, such area is steep, and as the effect the management of a dairy farm located in such area is quite expensive, not to mention, the landslide which becomes a common phenomenon in mountainous areas. Therefore, it is necessary to understand the availability and nutrient contents of forages and other natural resources during dry and wet seasons in order to formulate feeding systems based on forages so as to improve the productivity of dairy cows raised by smallholder farmers in Yogyakarta.

\section{Materials and Methods}

\section{Area and purposive sampling}

The respondents were 83 dairy farmers from three districts in Yogyakarta Province, Indonesia. The districts were Sleman, Bantul and Yogyakarta city. The study was conducted by survey method (interviews, questionnaires, field observations, focus group discussion and feed sampling) at the cooperative unit, farmers, dairy farmers, dairy farmer's groups and farming location in one of the areas of dairy cattle cooperation. In addition, the data also be strengthened by secondary data from relevant agencies.

\section{Collection and nutritional analysis of feed samples}

Representative samples of feed from each farm group were collected in polyethylene bags containing $200-250 \mathrm{~g}$ (concentrate) and 750 - 1,000 g (forages) fresh weight, and taken to the laboratory for chemical analysis. Analysis of samples was conducted in the Laboratory of Dairy Science and Milk Industry, Faculty of Animal Science UGM. The forage samples were dried and ground to pass through $2 \mathrm{~mm}$ sieve. Chemical composition for dry matter (DM), organic matter $(\mathrm{OM})$, crude protein $(\mathrm{CP})$, crude fiber $(\mathrm{CF})$, ether extract (EE) and total digestible nutrient (TDN) were determined following the methods of AOAC (1995); and neutral detergent fiber (NDF) and acid detergent fiber (ADF).

\section{Microenvironment identification}

Temperature and humidity were measured at intervals of 3 hours with a hygrometer. Observations began at 03:00, 06:00, 09:00, 11:00, 13:00, 15:00, 18:00 and 21:00. Observations of these environmental conditions were carried out for 2 weeks. After the temperature and humidity data were obtained, it is then used to calculate the Temperature Humidity Index (THI) by using formula (Mader et al 2006):

$\mathrm{THI}=(0.8 \times \mathrm{Tdb})+((\mathrm{RH} / 100) \times(\mathrm{Tdb}-14.4))+46.4$

$\mathrm{Tdb}=$ Ambient temperature $\left({ }^{\circ} \mathrm{C}\right)$

$\mathrm{RH}=$ Relative Humidity $(\%)$

THI data obtained to identify the level of stress experienced by cows by performing physiological observations.

\section{Data analysis}

The data obtained were analyzed through descriptive statistics with Statistical Program for Social Science version 16.0 .

\section{Results and Discussion}

\section{Characteristics of respondent dairy farmer's}

The general characteristics associated with household respondents were distributed by sex, age, educational status, experience in dairy keeping and the number of family member was presented in Table 1. From the total interviewed $(n=83)$, the majority of the respondents $(69.90 \%)$ were male while the remaining $(30.10 \%)$ were female. The majority of the respondents were aged between 36 - 55 years $(60.53 \%)$. This result showed that people in the most productive age are actively engaged in dairy activities. Of the total households interviewed, $98.79 \%$ are married. Concerning to level of education, the highest percentage $(34.72 \%)$ of the respondents completed elementary school, $30.56 \%$ completed Junior high school, $25 \%$ Senior high school, while $4.17 \%$ went through university/college and above. However, $5.56 \%$ of the respondents had not attended any formal or informal education. A total of $42.47 \%$ of the respondents had $11-20$ years experience in dairy keeping.

Microenvironment identification in dairy farms Yogyakarta (Colony pens)

Environmental factors such as the climate can interfere with the productivity, reducing the feed consumption and weight gain of dairy cows. Table 2 showed the result of observation microenvironment condition in dairy farms Yogyakarta (Colony pens). 
Table 1 Characteristics (age, formal education, length of experience and family size) of dairy farmers.

\begin{tabular}{|c|c|c|}
\hline Parameters & No of Person & Percentage $(\%)$ \\
\hline \multicolumn{3}{|l|}{ Age (years) } \\
\hline$\leq 15$ & 0 & 0 \\
\hline $16-25$ & 2 & 2.63 \\
\hline $26-35$ & 6 & 7.89 \\
\hline $36-45$ & 19 & 25.00 \\
\hline $46-55$ & 27 & 35.53 \\
\hline $56-65$ & 13 & 17.11 \\
\hline$\geq 65$ & 9 & 11.84 \\
\hline \multicolumn{3}{|l|}{ Formal education } \\
\hline No schooling & 4 & 5.56 \\
\hline Elementary school & 25 & 34.72 \\
\hline Junior high school & 22 & 30.56 \\
\hline Senior high school & 18 & 25.00 \\
\hline College/University & 3 & 4.17 \\
\hline \multicolumn{3}{|c|}{ Experience raising dairy cattle (year) } \\
\hline$\leq 10$ & 26 & 35.62 \\
\hline $11-20$ & 31 & 42.47 \\
\hline$\geq 21$ & 16 & 21.92 \\
\hline$\overline{\text { Average }}$ & $15.92 \pm 10.14$ & \\
\hline \multicolumn{3}{|c|}{ Number of family member (person) } \\
\hline$\leq 2$ & 18 & 24.32 \\
\hline $3-4$ & 40 & 54.05 \\
\hline $5-6$ & 14 & 18.92 \\
\hline$\geq 7$ & 2 & 2.70 \\
\hline Average & $3.57 \pm 1.28$ & \\
\hline
\end{tabular}

Table 2 shows that the highest temperature in the enclosure is reached at $12: 00$ hours was $34.6 \pm 1.33^{\circ} \mathrm{C}$ while the lowest temperature is reached at 08:00 hours was $25.8 \pm 1.82^{\circ} \mathrm{C}$. The average daily temperature is $31.3 \pm 1.28^{\circ} \mathrm{C}$. According to Yousef (1985), the temperature at Dairy Farms Yogyakarta is in accordance with the dairy cattle Thermo Neutral Zone (TNZ) ranging from $16-25^{\circ} \mathrm{C}$. But at certain hours that is 10:00 to 17:00 temperatures are above the TNZ so that the cows begin to experience stress. The highest humidity was reached at 08:00 hours was $82.0 \pm 8.72 \%$ while the lowest humidity was reached at 12:00 hours was $52.0 \pm 7.94 \%$. The average daily humidity is $64.1 \pm 8.77 \%$. Humidity in the cage is relatively low because of low rainfall in Yogyakarta. The impact of low humidity in the cage then the cow will make adjustments by increasing the frequency of respiration and feed intake.

The FH cows will show the best performance of production when placed at an ambient temperature of $18.3^{\circ} \mathrm{C}$ with $55 \%$ moisture, when exceeding that temperature the cows will adjust physiologically and behaviorally (Yani and Purwanto 2006). The gain of heat from outside the body (heat gain) will increase the heat load for the $\mathrm{FH}$ cow, if the temperature is higher than the comfortable temperature. $\mathrm{FH}$ cattle will lose body heat (heat loss) when the temperature is lower than the comfortable temperature. Daily temperature and humidity in Indonesia are generally high, ranging from 24 $-34^{\circ} \mathrm{C}$ and $60-90 \%$ humidity. These conditions greatly affect the level of productivity of FH cows and cause the evaporation process of the body of the cow will be inhibited, so that experiencing heat stress. Heat stress can reduce reproduction efficiency by $40-50 \%$ and decrease milk production by 15 $20 \%$ (St-Pierre et al 2003). Heat stress is negatively affecting endocrine and follicle development such as short duration of estrus and low oocyte quality, which may lead to low fertility in dairy cows (Wolfenson et al 1995). Table 2 shows that the THI value starting at 08:00 has an increase of 76.2 \pm 2.84 , and the highest THI is reached at 15:00 hours was $84.7 \pm 0.46$ meaning starting at 08:00 cows begin to experience mild stress due to THI $>72$. Until 17:00 THI value is still $>72$ that is $83.1 \pm 2.30$ so that starting at 08:00 to $17: 00$ hours dairy cows in Dairy Farm Yogyakarta experiencing mild to severe stress levels. The daily average THI is $82.1 \pm 1.86$. This is not in accordance with the opinion of Yani and Purwanto (2006) stating that the cow will be in a mild stress if the THI value 72 -79 .

Table 2 Environment condition and THI in dairy farms.

\begin{tabular}{lccc}
\hline Observation times & Temperature $\left({ }^{\circ} \mathrm{C}\right)$ & Humidity (\%) & THI \\
\hline $08: 00$ & $25.8 \pm 1.82$ & $82.0 \pm 8.72$ & $76.2 \pm 2.84$ \\
$10: 00$ & $31.9 \pm 2.13$ & $55.0 \pm 8.66$ & $81.4 \pm 2.94$ \\
$12: 00$ & $34.6 \pm 1.33$ & $52.0 \pm 7.94$ & $83.7 \pm 2.04$ \\
$13: 00$ & $32.9 \pm 0.59$ & $54.7 \pm 9.29$ & $83.3 \pm 0.58$ \\
$15: 00$ & $31.4 \pm 0.90$ & $75.3 \pm 9.07$ & $84.7 \pm 0.46$ \\
$17: 00$ & $31.2 \pm 0.89$ & $65.7 \pm 8.96$ & $83.1 \pm 2.30$ \\
Average & $31.3 \pm 1.28$ & $64.1 \pm 8.77$ & $82.1 \pm 1.86$ \\
\hline
\end{tabular}

Feed availability on the dry and wet season in Yogyakarta

Results of a survey conducted in the three districts showed that supplies of forage (grass, legume), agricultural by-products, concentrates ingredients and commercial concentrates were available throughout the year, although the amounts were not much and did not meet the total requirements by the animals. Table 3 shows that in the area of Yogyakarta province, many dairy smallholders used agricultural by-products as supplementary feed for livestock. However, the use of new technologies to improve the quality of the feed material was minimum. In addition, farmers rarely conserve the forages in the long term to cope with the needs during the dry season. According to Handayanta et al (2014) farmers had problems of utilizing dry land for growing forages, due to nutrient-poor soils, shortage of water and generally not suitable for growing food and pasture crops. Therefore, the soil and water factors contribute to the poor production of food crops and by-products resulting in the fluctuations in the availability of forage, which happens periodically every year during the dry and wet season. The quantity, quality, and continuity of forage were not guaranteed throughout the year resulting in poor animal productivity.

Feed availability is also dependent on the season and cropping pattern and the time of harvesting agricultural crops (Zemmelink et al 2003). Hence, the development of ruminant production at the farm level is positively related to the availability of feed resources and the socio-economic status of 
Table 3 Accessibility of feed and by-products to farmers during dry and wet seasons in Yogyakarta.

\begin{tabular}{lcccccc}
\hline \multirow{2}{*}{ Feed Type } & \multicolumn{3}{c}{ Dry season } & \multicolumn{3}{c}{ Wet season } \\
\cline { 2 - 7 } & Early & Mid & End & Early & Mid & End \\
\hline Diet types: & 3 & 2 & 2 & 3 & 4 & 3 \\
Grasses & 2 & 2 & 2 & 2 & 2 & 2 \\
Legumes & 2 & 2 & 2 & 2 & 3 & 3 \\
$\begin{array}{l}\text { Weeds } \\
\text { Agricultural by- }\end{array}$ & 3 & 2 & 2 & 3 & 3 & 3 \\
$\begin{array}{l}\text { products } \\
\text { Average feed }\end{array}$ & 3 & 2 & 2 & 3 & 3 & 3 \\
availability & & & & & & \\
\hline
\end{tabular}

Grasses: Cynodon dactylon var. dactylon, Cynodon dactylon (L.)

Pers, Pennisetum purpureum, Pennisetum purpureum cv Mott, Pennisetum purporhoides, Corn stover, Eleusine indica, etc. Legumes: Calliandra calothyrsus, Gliricidia sepium, Albizia chinensis, etc. Agriculture by-products: Wheat bran and pollard, cassava, cassava waste, rice bran, rice straw, corn flour, tofu waste, soybean seed husk, etc.

$0=$ No access to feed; $1=<25 \%$ farmers has access to feed; $2=25$ - $50 \%$ farmers has access to feed; $3=51-75 \%$ farmers has access to feed; $4=>76 \%$ farmers has access to feed.

the community. Supply of animal feed derived from plants (forage, agricultural by-products, and tree-crops forages) including land availability are affected by this condition (Marjuki et al 2000; Zemmelink et al 2003). The survey on the supply of grasses and legumes showed that that in the beginning of the wet season grasses and legumes were available in sufficient quantities, during the mid-season the production was more than adequate, and then began to decrease at the end of the wet season and up to the dry season. For agricultural waste, plantation, the material of concentrates and commercial concentrates looks pretty stable conditions and its availability. In dryland agricultural crops harvest between one another is not the same, so the availability of forage derived from agricultural by-products vary from time to time. At harvest crops, agricultural by-products which can be used as animal feed is abundant and not even all used for animal feed, there's something rotten or burned, on the other hand in the dry season to meet the needs of animal feed difficulties occur (Handayanta et al 2014). Efforts to increase the availability of feed as well as feed cost efficiency efforts can be done by finding new sources of feed that have not been commonly used by breeders (unconventional feed ingredients). According Anggraeny and Umiyasih (2008), reported that in some areas there are several kinds of waste agriculture and plantations that have not been commonly used as feed by farmers, for example, corncob, soybean husk, soybean seed husk, skin cassava, cassava stems, brown husk, and coffee husk; but in many other areas are already using such materials as animal feed.

\section{Composition and nutritional value of available feedstuffs}

The major feed resources available on the farms in this study are shown in Table 4 and 5. In the present study, eleven different feed resources were identified and categorized into: natural pasture grazing, rice straw, corn stover, forage feeds (fresh or succulent grasses and legumes), concentrates material (rice bran, copra meal, cassava waste, soybean seed husk, grains, molasses, wheat bran, and pollard), and commercial concentrate. Similar feedstuffs were shown in previous studies (Adugna 2008; Sintayehu et al 2008), who reported native pasture, rice straw, corn stover, agriculture byproducts, commercial concentrate, and non-conventional feeds were the most prevalent feed resources used by urban dairy producers in different parts of Yogyakarta province, Indonesia.

Table 4 Types of forages and agricultural by-products as energy and protein sources in dairy farms.

\begin{tabular}{llll}
\hline No & \multicolumn{1}{c}{ Feed types } & \multicolumn{1}{c}{ Forages } & \multicolumn{1}{c}{ Concentrates } \\
\hline 1 & Energy feeds/Source of energy & 1. Cynodon dactylon var. Dactylon & 1. Cassava \\
& 2. Cynodon dactylon $($ L.) Pers & 2. Cassava waste \\
& 3. Pennisetum purpureum & 3. Tofu waste (dregs soybean fermented) \\
& 4. Pennisetum purpureum cv Mott & 4. Soybean seed husk (boiled) \\
& 5. Pennisetum purporhoides & 5. Corn flour (ampok corn) \\
& 6. Corn stover & 6. Rice bran \\
& 7. Tanzania grass & 7. Wheat pollard type A \\
& 8. Merapi grass & 8. Wheat pollard type B \\
& 9. Eleusine indica & 9. Wheat pollard type C \\
& 10. Imperata cylindrical & \\
& 11. Signal grass & \\
& 12. Panicum maximum & \\
& 13. Rice straw (Oryza sativa) & \\
& 14. Ageratum conyzoides (weeds) & \\
& 15. Hibiscus leaves (Hibiscus similis BI) & \\
& 16. Banana leaves (Musa paradisiaca) & \\
& 17. Cassava leaves (Manihot utilissima) & \\
& 1. Gliricidia sepium & 1. Soybean seed husk (pounded) \\
& 2. Albizia chinensis & 2. Commercial concentrate \\
\hline
\end{tabular}


Table 5 Proximate composition, TDN, NDF, ADF and calculated NEL of forages and agricultural by-products collected form dairy smallholder in Yogyakarta.

\begin{tabular}{|c|c|c|c|c|c|c|c|c|c|c|}
\hline \multirow{2}{*}{ No } & \multirow{2}{*}{ Feed Types } & \multirow{2}{*}{$\begin{array}{l}\text { DM } \\
(\%) \\
\end{array}$} & \multicolumn{5}{|c|}{ Analysis Nutritional (\% DM) } & \multirow{2}{*}{$\begin{array}{c}\text { NEL } \\
\text { (Mcal) }\end{array}$} & \multirow{2}{*}{$\begin{array}{c}\text { NDF } \\
(\%)\end{array}$} & \multirow{2}{*}{$\begin{array}{c}\text { ADF } \\
(\%)\end{array}$} \\
\hline & & & OM & $\mathrm{CP}$ & $\mathrm{EE}$ & $\mathrm{CF}$ & TDN & & & \\
\hline 1 & Cynodon dactylon var. Dactylon & 32.61 & 89.31 & 7.52 & 1.91 & 26.83 & 59.89 & 1.35 & 63.20 & 31.20 \\
\hline 2 & Cynodon dactylon (L.) Pers & 24.28 & 86.81 & 9.39 & 2.22 & 27.28 & 57.58 & 1.29 & 56.84 & 30.80 \\
\hline 3 & Pennisetum purpureum & 29.18 & 86.28 & 8.84 & 1.88 & 32.36 & 53.82 & 1.20 & 66.70 & 37.59 \\
\hline 4 & Pennisetum purpureum cv Mott & 21.58 & 87.97 & 11.55 & 2.29 & 31.22 & 55.77 & 1.25 & 59.67 & 33.90 \\
\hline 5 & Pennisetum purporhoides & 26.88 & 87.19 & 7.01 & 1.96 & 34.87 & 50.98 & 1.13 & 67.76 & 37.43 \\
\hline 6 & Corn stover & 46.20 & 82.20 & 9.90 & 1.90 & 29.60 & 54.30 & 1.21 & 70.40 & 44.40 \\
\hline 7 & Tanzania grass & 33.99 & 88.55 & 8.00 & 1.38 & 31.89 & 56.12 & 1.25 & 66.70 & 39.37 \\
\hline 8 & Merapi grass & 32.87 & 90.22 & 5.22 & 0.92 & 33.64 & 55.14 & 1.23 & 70.11 & 40.29 \\
\hline 9 & Eleusine indica & 33.60 & 90.61 & 5.38 & 0.92 & 39.32 & 53.59 & 1.19 & 73.75 & 46.84 \\
\hline 10 & Imperata cylindrical & 21.23 & 90.41 & 9.93 & 2.08 & 34.02 & 54.43 & 1.21 & 65.58 & 39.16 \\
\hline 11 & Signal grass & 24.36 & 90.52 & 6.00 & 1.52 & 32.37 & 54.04 & 1.20 & 67.55 & 36.37 \\
\hline 12 & Panicum maximum & 25.80 & 83.63 & 5.67 & 1.87 & 31.32 & 51.33 & 1.14 & 66.79 & 41.32 \\
\hline 13 & Gliricidia sepium & 21.15 & 92.48 & 23.06 & 3.20 & 18.83 & 77.22 & 1.77 & 31.49 & 23.69 \\
\hline 14 & Albizia chinensis & 33.33 & 94.17 & 20.05 & 1.79 & 19.81 & 71.96 & 1.64 & 46.66 & 36.58 \\
\hline 15 & Calliandra calothyrsus & 33.91 & 94.50 & 22.02 & 1.36 & 22.27 & 67.44 & 1.53 & 37.27 & 27.80 \\
\hline 16 & Ageratum conyzoides (weeds) & 22.45 & 90.63 & 12.07 & 1.75 & 30.59 & 58.86 & 1.32 & 48.35 & 34.87 \\
\hline 17 & Rice straw (Oryza sativa) & 41.00 & 81.82 & 3.89 & 1.26 & 30.23 & 42.88 & 0.93 & 70.68 & 43.25 \\
\hline 18 & Hibiscus leaves (Hibiscus similis BI) & 37.53 & 87.87 & 11.24 & 1.99 & 28.12 & 58.31 & 1.31 & 55.26 & 29.06 \\
\hline 19 & Banana leaves (Musa paradisiaca) & 22.43 & 88.69 & 17.13 & 4.27 & 23.95 & 69.31 & 1.58 & 58.87 & 31.41 \\
\hline 20 & Cassava leaves (Manihot utilissima) & 22.18 & 90.25 & 16.56 & 2.43 & 32.05 & 59.29 & 1.33 & 45.75 & 33.59 \\
\hline 21 & Cassava & 31.73 & 97.18 & 1.52 & 0.60 & 3.74 & 82.56 & 1.90 & 17.67 & 3.73 \\
\hline 22 & Cassava waste & 84.26 & 98.05 & 2.16 & 0.11 & 23.52 & 82.39 & 1.90 & 53.60 & 28.05 \\
\hline 23 & Tofu waste (dregs soybean fermented) & 10.04 & 98.05 & 14.99 & 16.42 & 25.03 & 71.22 & 1.62 & 51.93 & 25.63 \\
\hline 24 & Soybean seed husk (boiled) & 14.03 & 97.33 & 13.74 & 1.59 & 41.94 & 53.92 & 1.20 & 62.36 & 46.49 \\
\hline 25 & Soybean seed husk (pounded) & 83.24 & 94.78 & 29.55 & 7.47 & 23.46 & 69.43 & 1.58 & 41.25 & 24.48 \\
\hline 26 & Corn flour (ampok corn) & 86.12 & 96.56 & 12.11 & 2.72 & 7.15 & 73.84 & 1.69 & 53.57 & 8.29 \\
\hline 27 & Rice bran & 89.86 & 92,29 & 6.31 & 1.18 & 30.77 & 46.91 & 1.03 & 62.31 & 44.49 \\
\hline 28 & Wheat pollard type A & 83.98 & 95.47 & 14.71 & 0.58 & 14.02 & 61.68 & 1.39 & 47.38 & 15.30 \\
\hline 29 & Wheat pollard type B & 84.28 & 94.43 & 17.95 & 0.55 & 12.95 & 56.19 & 1.26 & 49.23 & 14.33 \\
\hline 30 & Wheat pollard type C & 83.51 & 94.69 & 15.96 & 0.31 & 14.00 & 57.17 & 1.28 & 50.25 & 15.35 \\
\hline 31 & Commercial concentrate & 85.57 & 94.60 & 21.84 & 0.11 & 16.89 & 68.62 & 1.56 & 44.39 & 12.62 \\
\hline 32 & Mineral mix & 90.00 & 98.10 & 0.00 & 0.00 & 0.00 & 0.00 & 0.00 & 0.00 & 0.00 \\
\hline
\end{tabular}

$\mathrm{DM}$ = Dry matter; $\mathrm{OM}=$ Organic matter; $\mathrm{CP}=$ Crude protein; $\mathrm{EE}=$ Ether extract; $\mathrm{CF}=$ Crude fibre; $\mathrm{TDN}=$ Total digestible nutrient; $\mathrm{NEL}$

$=$ Net energy lactation; $\mathrm{NDF}=$ Neutral detergent fiber; $\mathrm{ADF}=$ Acid detergent fiber.

Regardless of farm size, the majority of interviewed farmers used forages as the main basal diet for cattle, especially during the wet seasons. Forage feeds were mainly available from October to March (wet season) which were purchased or obtained from open areas for free. There was great variation in the type of feed used during both of the dry and wet seasons, and rice straw was the most dominant type of feed used. During harvesting season, rice straw was most widely used for feeding cattle, up to $78 \%$ of the farmers (Marjuki et al 2000). This was due to the extensive cultivation of rice crops compared to other crops. Hence, the production of rice straw was also highest among the types of forages or other agricultural by-products. Rice is the main crops grown by farmers (Winarto et al 2000) and rice straw is the easiest and most widely forage conserved, and most often purchased by farmers (Handayanta et al 2014).

Other forages were little used as cattle feed (in terms of frequency and total DM consumption) and included Leucaena leaves, sesbania leaves (legumes), cassava leaves, soybean straw, and mungbean straw (agricultural by-product), acacia leaves, mahogany leaves, banana leaves, etc. (forage trees) (Handayanta et al 2014). It was observed that dairy farmers in this survey did not restrict themselves to the use of conventional feed resources only, but made use of locally available non-conventional feed resources, particularly during the dry seasons. Rice straw, cassava waste, soybean seed husk and tofu waste (dregs soybean fermented) were utilized most by farmers owning small farm size, who cannot afford to purchase agriculture by-products and commercial concentrate due to financial limitations.

In general, the availability of feed resources varied across seasons, and farmers utilized whatever that was available for feeding dairy cattle. During the wet and dry season, concentrate supplements and forage feeds were the most widely used feed resources, whereas during the dry season the poor quality natural pasture for those who grazed their dairy cattle, conserved rice straw, corn stover, concentrates, non-conventional feeds were important feed resources. According to the respondents, this variation in seasonal feed availability and quality resulted in low milk production and low income. Thus, it is important to effectively utilize the available feed resources and provide concentrate 
supplements to alleviate the feed shortage and maximize milk production of dairy cows.

\section{Conclusion}

The starting at 08:00 to 17:00 hours dairy cows in dairy farms of Yogyakarta experiencing mild to severe stress levels. Farmers had better access to forages and agricultural byproducts in the wet season than the dry season, nevertheless, they needed to purchase commercial concentrates in both seasons. To achieve high productivity the continuity and availability of forages and concentrate in this area need to be assured to reduce the dependency on the flow of feedstuffs from outside of the region.

\section{Acknowledgements}

This study was supported by PTUPT Grant 2018 from the Directorate of Higher Education, the Ministry of Research, Technology and Higher Education, Republic of Indonesia (RISTEKDIKTI-RI) and Universitas Gadjah Mada.

\section{References}

Adugna T (2008) Feed resources and feeding management: a manual for feedlot operators and development workers. Ethiopian Sanitary \& Phytosanitary Standards and Livestock \& Meat marketing Program (SPS-LMM) Texa Agricultural Experiment Station (TAES)/Texas A\&M University System, Addis Ababa.

Anggraeny YN, Umiyasih U (2008) Evaluasi potensi pakan asal limbah tanaman pangan dan limbah perkebunan di daerah prioritas kawin alam mendukung program P2SDS. Seminar Nasional Teknologi Peternakan dan Veteriner 304-311.

Association of Official Analytical Chemist (AOAC) (1995) Official Methods of Analysis. 16th Edition, Association of Official Analytical Chemist, Washington DC., USA.

Badan Pusat Statistik (BPS) (2010) Statistik Indonesia 2010 [Statistics Indonesia 2010]. Badan Pusat Statistik (BPS), Jakarta, Indonesia, (In Indonesian).

Direktorat Jenderal Peternakan dan Kesehatan Hewan (Dirjen PKH) (2017) Livestock and Animal Health Statistic 2017. Ministry of Agriculture RI. Jakarta. p. 84. http://ditjenpkh.pertanian.go.id (In Indonesia).

Handayanta E, Ifar S, Hartutik, Kusmartono (2014) Botanical composition and quality of ruminant feed resources in the dry land farming areas in Yogyakarta, Indonesia. Journal of Biology, Agriculture and Healthcare 4:26-33.
Hernawan AE (2014) Effect of banana peel application in ration on hematological level, nitrogen retention and body weight gain of heat exposed broiler chicken. Sci Pa.: Ser D Anim Sci 42:101-107.

Mader TL, Davis MS, Brown-Brandl T (2006) Environmental Factors Influencing Heat Stress in Feedlot Cattle. J Anim Sci 84:712719.

Marjuki, Zemmelink G, Ibrahim MNM (2000) Cattle production on small holder farms in East Java, Indonesia. II. Feeds and feeding practices. Asian-Aust J Anim Sci 13:226-235.

Rochijan, Widyobroto BP, Ismaya (2016) Effect of High Rumen Undegraded Protein (HRUP) supplementation on estrous response and progesterone hormone profile in dairy cows raised under Indonesia tropical environmental conditions. Asian J Anim Sci 10:175-181.

Sintayehu Y, Fekadu B, Azage T, Berhanu G (2008) Dairy production, processing and marketing systems of Shashemene-Dilla area, South Ethiopia. In: Solano C, Bernues A, Rojas F, Joaquin N (eds.) IPMS (improving productivity and market success) of Ethiopian farmer's project working paper 9, ILRI (International Livestock Research Institute), Nairobi, Kenya, p. 62.

St-Pierre NR, Cobanov B, Schnitkey G (2003) Economic losses from heat stress by US livestock industries. J Dairy Sc. 86:E52-E77.

Thayeb TMH (2015) Profile of Indonesia. Embassy of the Republic of Indonesia, November 24, 2015.

Winarto PS, Leegwater PH, Zemmelink G, Ibrahim MNM (2000) Cattle production on small holder farms in East Java, Indonesia. I. Household and farming characteristics. Asian-Aust J Anim Sci $13: 220-225$

Zemmelink G, Ifar S, Oosting SJ (2003) Optimum utilization of feed resources: Model studies and famer's practices in two villages in East Java, Indonesia. Agricultural System 76:77-94.

Widyobroto BP, Rochijan, Noviandi CT, Astuti A (2018) Dairy cows productivity and socio-economic profile of dairy smallholder's communities in Yogyakarta, Indonesia. IOP Conf. Series: Earth and Environmental Science 119:012060.

Wolfenson DW, Thatcher W, Badinga L, Savio JD, Meidan R, Lew BJ, Braw-Tal R, Berman A (1995) Effect of heat stress on follicular development during the estrous cycle in lactating dairy cattle. J Biol Rep 52:1106-1113.

Yani A, Purwanto BP (2006) Pengaruh iklim mikro terhadap respons fisiologis sapi Peranakan Fries Holland dan modifikasi lingkungan untuk meningkatkan produktivitasnya (ULASAN). Media Peternakan 29:35-46.

Yousef MK (1985) Stress Physiology in Livestock. Vol. 1. Boca Raton: CRC Press. 